\title{
Параллели эпических формул в якутском олонхо и тувинском эпосе: сравнительный аспект
}

\author{
Юрий П. Борисов
}

Северо-Восточный федеральный университет имени М. К. Аммосова, Российская Федерация

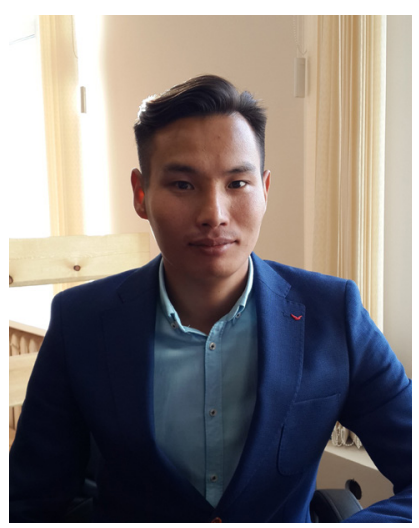

Целью статьи является выявление параллелей и установление универсалий между якутским олонхо и тувинским эпосом на уровне эпических формул. В исследовании основным методом был индуктивный метод, который позволяет обобщить результаты применения метода сплошной выборки, метода верификации, метода описания, методов компонентного и контекстуального анализа.

В ходе исследования из текста тувинского эпоса «Боктуг Кириш, Бора Шэлей» сказителя М. Н. Ооржака всего были выявлены 82 эпические формулы, при этом обнаружены параллели в 17 примерах, из них в статье проанализированы 9 формул с их аналогами из текстов якутского олонхо (нескольких версий).

Установлено, что рассмотренные примеры являются типическими местами. Универсальность формул заключается в их интертекстуальности. При этом структурные особенности эпических формул свидетельствует о стадиальном отличии сравниваемых эпических систем. А семантическая нагрузка эпических формул исходит из ядерных лексем и периферийных элементов, которые подобраны по принципам дословного повтора и начальной аллитерации. В некоторых примерах, особенно организованных посредством матричной конструкции, наблюдаются полные эквиваленты в ключевых лексемах.

В связи с изложенным автор считает, что рассмотренные параллели эпических формул являются результатом генетического родства тувинского эпоса и якутского олонхо, которые сохранились благодаря принципу ритмико-синтаксического параллелизма.

Ключевые слова: якутский фольклор; тувинский фольклор; народный эпос; олонхо; ядерная лексема; периферийный элемент; ритмико-синтаксический параллелизм; эпическая формула; типическое место; устойчивая конструкция; параллель; универсалия

Исследование выполнено в рамках научно-исследовательского проекта СВФУ «Героические эпосы тюрко-монгольских народов Евразии: проблемы и перспективы сравнительного изучения».

\section{Для цитирования:}

Борисов Ю. П. Параллели эпических формул в якутском олонхо и тувинском эпосе: сравнительный аспект // Новые исследования Тувы. 2020, № 4. С. 250-260. DOI: www.doi.org/10.25178/nit.2020.4.17

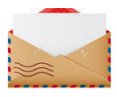

Борисов Юрий Петрович - кандидат филологических наук, старший научный сотрудник - заведующий сектором «Лингвофольклористика» Научно-исследовательского института Олонхо Северо-Восточного федерального университета имени М. К. Аммосова. Адрес: 677000, Россия, г. Якутск, ул. Белинского, д. 58. Тел.: +7 (924) 661-20-44. Эл. адрес: olonhoman@mail.ru

BORISOV, Yuri Petrovich, Candidate of Philology, Senior Research Fellow, Head, Sector of Linguistic Studies of Folklore, Olonkho Research Institute, M. K. Ammosov North-Eastern Federal University. Postal address: 58 Belinsky St., 677000 Yakutsk, Russian Federation. Tel.: +7 (924) 661-20-44. Email: olonhoman@mail.ru ORCID ID: 0000-0002-0265-373X 


\title{
Parallels of epic formulas in the Yakut olonkho and Tuvan epic: a comparative aspect
}

\author{
Yuri P. Borisov \\ M.K. Ammosov North-Eastern Federal University, Russian Federation
}

The article aims to identify parallels and establish the cultural universals shared by the Yakut olonkho and the Tuvan epic at the level of epic formulas. The main methodology of the study was that of induction, which allows to summarize the outcomes of complete sampling, verification and description methods, as well as of component and contextual analysis.

This study revealed the total of 82 epic formulas in the text of the Tuvan epic "Boktug Kirish, Bora Sheley" as told by storyteller M. N. Oorzhak, as well as parallels in 17 examples. 9 formulas were specifically analyzed in the article, with analogues found in the texts of the Yakut olonkho (several versions).

The article treats these examples as 'typical places', universal in their intertextuality. At the same time, the structural features of the epic formulas reflect the stadial difference between the epic systems under comparison. The semantic load of epic formulas comes from their nuclear lexemes and peripheral elements, which are selected according to the principles of literal repetition and alliterative beginnings. Some examples, especially those organized with the use of a matrix construction, show the presence of full equivalents across key lexical items.

The author concludes that considered parallels of the epic formulas have been determined by the genetic relationship between the Tuvan epic and the Yakut olonkho. These parallels have survived due to the general principle of rhythmic-syntactic parallelism.

Keywords: Yakut folklore; Tuvan folklore; folk epic; olonkho; nuclear lexeme; peripheral elements; rhythmic and syntactic parallelism; epic formula; typical place; parallel; universal feature

\section{Financing}

The study is part of the research project "Heroic epic of the Turkic and Mongolian peoples of Eurasia: problems and prospects of a comparative study" supported by the North-Eastern Federal University.

\section{For citation:}

Borisov Yu. P. Paralleli epicheskikh formul v iakutskom olonkho i tuvinskom epose: sravnitel'nyi aspekt [Parallels of epic formulas in the Yakut olonkho and Tuvan epic: a comparative aspect]. New Research of Tuva, 2020, no. 4, pp. 250-260 (In Russ.). DOI: www.doi.org/10.25178/nit.2020.4.17

\section{Введение}

Еще в 1955 г. А. П. Окладниковым было установлено, что якутский героический эпос сформировался в то время, когда предки якутов проживали рядом с родственными им племенами Саяно-Алтайской локальности, с которыми активно взаимодействовали и вели тесные культурно-исторические контакты (Окладников, 2013: 36). Потому сравнительное изучение возможных связей якутского героического эпоса с другими тюркскими эпосами Сибири на уровне эпических формул представляется весьма актуальной задачей.

Целью настоящей статьи является выявление параллелей и установление универсалий между якутским олонхо и тувинским эпосом на уровне эпических формул, образованных на основе ритмикосинтаксического параллелизма.

И. В. Пухов писал, что сходство социальных, исторических и географических условий и культурного развития предков сибирских народов способствовало большей близости их эпических сказаний (Пухов, 2004: 63). Однако, как утверждает эпосовед, тувинские сказания, подобно алтайскому эпосу, в своих более поздних пластах значительно отличаются от олонхо в изображении врагов героя и их целей. И потому тувинский эпос вышел за рамки тематики олонхо, в которых главное место занимает борьба с чудовищами (там же: 125). В то же время, между якутским олонхо и ранним тувинским эпосом наблюдается общность, охватывающая особенности их стиля изложения, сюжетно-композиционной структуры и основных образов (там же: 133 ).

В свою очередь, М. Т. Гоголева, продолжая наблюдения И. В. Пухова, утверждает, что между якутским олонхо и тувинским эпосом наблюдаются генетические связи, которые охватывают сюжетно-ком- 
позиционную структуру, художественно-изобразительные средства и особенности сказительства (Гоголева, 2015: 95).

Именно благодаря генетическому родству между тюрко-монгольскими эпосами наблюдаются связи на уровне эпического стиха, которые, по мнению В. М. Жирмунского, заключаются в метрическом типе, основанном на ритмико-синтаксическом параллелизме (Жирмунский, 1964: 21). Исследователь также писал о характерности этого метрического типа для архаического эпоса тувинцев и якутов (там же: 21).

Из изложенного следует, что исследователи допускают возможность взаимосвязи якутского олонхо с тувинским эпосом на уровне стиля, в частности в их метрических структурах, выраженных ритмико-синтаксическим параллелизмом.

Новизна исследования заключается в выявлении и научном осмыслении степени взаимосвязи якутского олонхо и тувинского эпоса на уровне эпических формул, которое все еще остается вне поля зрения исследователей.

В ходе выполнения нашего исследования были применены методы: метод сплошной выборки, с помощью которого осуществлен подбор примеров для анализа из сравниваемых эпических текстов; описательный метод; метод верификации, способствующий обнаружению аналогов найденных формул; метод компонентного анализа, позволяющий изучить функциональную специфику ключевых слов и их значений в контексте эпической формулы; методы контекстуального анализа при выявлении семантической нагрузки эпических формул. При этом основополагающим методом проведенного исследования является индуктивный метод.

Источниковой базой для исследования послужили следующие эпические тексты: тувинский эпос «Боктуг-Кириш Бора-Шэлей» сказителя М. Н. Ооржака из серии «Памятники фольклора народов Сибири и Дальнего Востока» (12 т., 1997 г.), в сравнении с которым привлечены несколько опубликованных текстов олонхо: «Кыыс Дэбилийэ» (сказителя Н. П. Бурнашева), «Могучий Эр Соготох» (сказителя В. О. Каратаева), также изданные в рамках серии «Памятники фольклора народов Сибири и Дальнего Востока» (4 т., 1993 г. и 10 т., 1996 г.); «Буура Дохсун» (сказителя С.С. Яковлева, 1993 г.) и сравнительно новые издания: «Дыырай Бэргэн» (сказителя У. Г. Нохсорова, серия «Саха Боотурдара», т. 6, 2009 г.), «Девушка богатырь Джырыбына Джырылыатта» (сказителя П. П. Ядрихинского, 2011 г.), «Даадар Хара» (сказителя Н. П. Бурнашева, 2013 г.) и «Хаан Джаргыстай» (в записи И. А. Худякова, сказитель не известен, 2016 г.). Такой подход к источниковой базе обоснован тем, что общность в стилистических средствах, охватывающая основные особенности между якутским олонхо и тувинским эпосом, наблюдается только в древних пластах этих памятников (Пухов, 2004: 133). Ввиду этого в текстах якутского олонхо сравниваемые примеры из тувинского эпоса «рассеяны» по основному фонду текстов олонхо и потому не представляется возможным выбрать тот или иной конкретный текст олонхо для сравнения.

\section{Эпические формулы}

Прежде всего важно отметить, что изначальной структурной формой древнетюркского народного эпического стиха, как утверждает В. М. Жирмунский, были «эпические тирады», то есть эпические стихи различного объема, скрепленные ритмико-синтаксическим параллелизмом (Жирмунский, 1968: 32). Однако, в более поздних трудах отечественные и зарубежные исследователи-эпосоведы, а также сам В. М. Жирмунский пришли к выводу о том, что эпические тирады развились в эпические формулы.

Считаем необходимым отметить наиболее важные положения об эпических формулах, установленные в их трудах. Во-первых, в эпических формулах содержатся опорные слова, которые являются их организующей основой, задающей семантическую нагрузку эпической формулы (Гринцер, 1975: 172). Во-вторых, эпические формулы представляют собой опору для сказителей-импровизаторов, необходимую для их плодотворного творчества. Они организуют особый эпический язык, при помощи которого сказители раскрывают тему своего произведения в пределах эпического канона (Жирмунский, Кононов, 2007: 247). В-третьих, эпические формулы обладают высокой вариативностью, которая способствует созданию сказителем многочисленных новых вариантов эпических формул (Лорд, 1994: 14). В-четвертых, если семантическая нагрузка эпических формул исходит из их лексического наполнения, то в структурной организации эпических формул ключевое значение приобретает также их синтаксическая сторона (Артеменко, 1985: 4).

Кроме того, некоторые эпические формулы, ввиду их особой устойчивости, образуют «типические (общие) места» (loci communes). Эти устойчивые выражения, по мнению Н. В. Кидайш-Покровской и 
А. И. Мирбадалевой, весьма характерны для эпоса тюркоязычных народов (Кийдаш-Покровская, Мирбадалева, 1971: 64). По своей сути они являются интертекстуальными повторами, способствующими сохранению сюжетно-композиционной структуры эпоса (Кузьмина, 2005: 5). Типические места с точки зрения языка организуются посредством матричной конструкции с некоторыми отсутствующими ячейками, варианты заполнения которых у каждого сказителя индивидуальны, что способствует к вариации в структуре и семантике типических мест (Оссовецкий, 1979: 214).

Обращаясь к исследованиям, посвященным к изучению языка олонхо, отметим, что академик П. А. Слепцов в нем обнаруживает ярко выраженную формульность, указывает на наличие солидного пласта архаизмов и акцентирует широкую вариативность (Слепцов, 1990: 212). Формульность якутского олонхо исходит из основного организующего композиционного принципа - принципа параллелизма (Покатилова, 1996: 87). Вариативность языка олонхо определяется унифицированностью эпических формул, которая содействует сохранению преемственности эпических традиций (Дмитриев, 1978: 120). А их компактная форма способствует передаче колоссального объема предельно сжатой информации (Габышева, 2009: 80).

В свою очередь С. М. Орус-оол утверждает, что в языке тувинского эпоса, как и якутском олонхо, основным организующим принципом выступают синтаксический и образно-поэтический параллелизмы, в которых также наблюдается созвучие начальных слов и слогов, образующих поэтическую аллитерационную рифму (Орус-оол, 1997: 38). Кроме того, в нем содержатся типические места, которые отличаясь стабильностью и обобщенностью, обладают широким варьированием, зависящим от многих субъективных факторов (Орус-оол, 2013: 51). При этом, эпические формулы характеризуются постоянством лексического наполнения и отличаются единообразием синтаксического построения (Хертек, 2015: 188).

Тем самым можно убедиться в том, что, в целом, с теоретической точки зрения эпические формулы как якутского олонхо, так и тувинского эпоса преимущественно основываются на общем принципе для обоих языков - на принципе ритмико-синтаксического параллелизма, при организации которого исследователями особая роль отводится ключевым словам, несущим семантическую нагрузку эпических формул.

\section{Сравнительный анализ эпических формул}

В качестве материала исследования нами был выбран текст тувинского эпоса «Боктуг Кириш, Бора Шэлей» (5061 поэтических строк) в самозаписи от 1962 г. сказителя М. Н. Ооржака (1892-1968) (Ооржак, 1997).

В ходе анализа материала из текста тувинского эпоса всего выявлены 82 эпические формулы, образованные на основе ритмико-синтаксического параллелизма. Подбор формул осуществлялся исходя из наличия аналогичных конструкций в якутском олонхо.

Поскольку известно, что общность в стилистических средствах между якутским олонхо и тувинским эпосом обнаруживается только в их древних пластах (Пухов, 2004: 133), то обнаружение параллелей в рамках одного текста олонхо, ввиду их малого количества, представляется не возможным. Учитывая этот факт, при подборе примеров из якутского олонхо были привлечены эпические формулы из нескольких опубликованных текстов, о которых мы упоминали ранее.

В результате поиска параллелей в якутском олонхо оказалось, что из выявленных 82 тувинских примеров в олонхо наблюдаются соответствия только в 17 формулах.

Далее проанализируем наиболее интересные параллели эпических формул из тувинского эпоса и якутского олонхо:

Формула эпического времени:

Эртенгиниң эртезинде,

Бурунгунуң мурнунда ...
Раньше раннего, Прежде давнего [времени] ... 
Былыргы дьыл

Былдьаһыктаақын-быһылааннаақын

Быдан анараа өттүгэр,

Урукку күн

Охсуһуулаақын-оһоллооқун

Улақа өттүгэр,

Ааспыт дьыл

Алдьархайдаақын-арасхааттаађын

Анараа таһаатыгар...

(Бурнашев, 1993: 73).

За дальней далью

Беспокойных-тревожных

Древних лет,

По ту сторону

Ратно-бранных

Минувших дней,

За невидимой гранью

Лиходейно-бедовых

Канувших лет...

(Бурнашев, 1993: 73).

Если в тувинском эпосе формула эпического времени образована на основе двучленного ритмикосинтаксического параллелизма (далее - РСП), то в якутском олонхо - на основе трехчленного РСП. Ключевыми лексемами в тувинском примере являются эртенги - 'ранний' / бурунгу - 'прежний', а в якутском ключевые словосочетания: былыргы дыыл - 'древние года' / урукку күн - 'минувшие дни' / aаспыт дыыл - ‘прошедшие года'. При этом, если в формуле тувинского эпоса задействованы только ключевые лексемы без использования собственно периферийных лексем, то в якутском, кроме ядерных лексем, также содержатся дополнительные элементы, уточняющие эпическое время. В этом отношении формула эпического времени тувинского эпоса является максимально сжатой. Однако, основная сходная семантика формул сохраняется.

Формула «богатырь в гневе»:

Ажынмас боду ажынып,

Хорадавас боду хорадап келгеш...

(Ооржак, 1997: 400; здесь и далее в примерах выделено нами. - Ю. Б.).

Кыыһырбатах бэйэтэ

Кып-кыдьыттан кыыһыран барда. Абарбатах бэйэтэ

Аба-сата санын саннанна...

(Яковлев, 1993: 59).
Так разозлилась, как [прежде] не злилась,

Так рассердилась, как [прежде] не сердилась...

(Ооржак, 1997: 401).

Не сердившийся прежде

Стал сердиться сильно,

Не гневавшийся прежде

Стал сильно гневаться...

(Пер. наш. - Ю. Б.).

В тувинском эпосе и якутском олонхо главным персонажем является богатырь. Примечательно, что обе приведенные формулы образованы двучленными РСП, организованными посредством дословного повторения ключевых лексем. Если в тувинском примере ключевые лексемы выражены синонимами: ажынар / хорадаар - 'сердиться', то в якутском также используются ключевые слова, выраженные синонимичными лексемами с аналогичным содержанием: кыы ыы 'сердиться' / абар - 'гневаться'. Эти лексемы являются ядерными и их дословным повторением также образованы члены РСП. Вследствие этого как структура эпических формул, так и их смысловая нагрузка являются одинаковыми.

Формула, описывающая красоту прекрасной девушки:

Акызы көөрге, ыңай көөрге - ай херелдиг,

Бээр көөрге - хун херелдиг...

(Ооржак, 1997: 316).
Глянул брат [на нее]: вдаль посмотрит лунный свет [излучает],

Близ посмотрит - солнечный свет [излучает]...

(Ооржак, 1997: 317).
Ыйдаақар ыраас ньуурдаах,

Күннээъэр күндү бэйэлээх...

(Ядрихинский, 2011: 86).
С ликом луны светлее,

Солнца ясного дороже...

(Ядрихинский, 2011: 87). 
В сравниваемых формулах полностью совпадает семантическая нагрузка. Так как при раскрытии образа использованы эквивалентные лексемы, употребленные на оппозиции: ай (ыŭ) - ‘луна' / хун (күн) - 'солнце'. Важно заметить, что также сохранилось расположение ядерных лексем, что свидетельствует о непосредственной связи анализируемых примеров. Отличие состоит лишь в том, что в якутской формуле периферийные компоненты подобраны посредством начальной аллитерации, а в тувинской - дословным повторением.

Формула, описывающая езду богатырского коня:

\begin{tabular}{|c|c|c|}
\hline $\begin{array}{l}\text { Булуттуг дээрниң адаа-биле, } \\
\text { Будуктуг ыяштың кыры-биле... } \\
\qquad \text { (Ооржак, 1997: 474). }\end{array}$ & $\begin{array}{l}\text { Мчался [конь] ниже небес с облаками, } \\
\text { Выше деревьев с ветвями... }\end{array}$ & (Ооржак, 1997: 475). \\
\hline $\begin{array}{l}\text { Көтөр былыты аннынан, } \\
\text { Турар маһы үрдүнэн } \\
\text { Барқа баһаам } \\
\text { Барытын барда... } \\
\end{array}$ & $\begin{array}{l}\text { Под самыми летящими облаками, } \\
\text { Над самыми стоящими деревьями } \\
\text { Стал быстро } \\
\text { Скакать [конь]... }\end{array}$ & (Пер. наш. - Ю. Б.). \\
\hline
\end{tabular}

Как в тувинском эпосе, так и в олонхо, одним из основных является образ богатырского коня, езда которого гиперболизируется посредством сравнения с окружающей средой. Так, нами обнаружено соответствие эпических формул, образованных посредством двучленного РСП, в них полностью совпадают образы сравнения. Более того, ядерные лексемы первых членов РСП выражены эквивалентными словосочетаниями: булуттуг дээрниң - 'небеса с облаками' / көтөр былыты - ‘летящие облака’. А ядерные лексемы вторых членов синонимичны по отношению друг к другу: будуктуг ыяштың - ‘деревья с ветвями' / турар маһы - 'стоящие деревья’. Здесь важно отметить, что лексема будуктуг тувинского языка в якутском языке обозначается как мутуктаах - 'с ветвями' и в некоторых олонхо при реализации анализируемой формулы используются именно однотипные словосочетания, аналогичные тувинскому.

Формула, описывающая горечь:

Бир караандан чаш төгүлдүр,

Бир караандан хан төгүлдүр ыглап олурда, ...

(Ооржак, 1997: 328).

И, когда так заплакала, что полились слезы из одного глаза,

Полилась кровь из другого глаза,...

(Ооржак, 1997: 329).

Ханас харақыттан хаан аллыбыт,

Уна харақыттан уу субуруйбут,

(Яковлев, 2013: 153).
С левого глаза кровь течет,

С правого глаза слезы льются...

(Пер. наш. - Ю. Б.).

Интересно, что как в тувинском эпосе, так и в якутском олонхо, при описании горечи невосполнимой утраты используются аналогичные эпические формулы, состоящие из двучленных РСП. В них ключевыми являются эквивалентные лексемы: караандан / харақыттан - 'из глаз'; хаан / хан - 'кровь'; чаш / харах уута - 'слезы', которые образуют особо устойчивую матричную конструкцию. А остальные элементы представляют собой вариативную периферийную часть, которая в тувинской формуле подобрана по принципу дословного повторения бир - 'один'; төктүр - 'пролиться', а в якутской антонимическими: ханас - 'левый’ / уна - 'правый’ и синонимическими лексемами аллыбыт 'протечь' / субуруйбут - 'протянуться’.

Формула, описывающая продолжительность действия:

Кыш болганын хыраазындан билип,

Хылырады хүрежип,

Чайның шалыңындап билип,

Шалырады хүрежип турда, ...

(Ооржак, 1997: 404).
О наступлении зимы по инею узнают:

Борются - скрипит [под ногами];

О лете по росе узнают

Борются - шуршит [под ногами].

(Ооржак, 1997: 405). 
Күһүннүтүн өксүөнүнэн билэн, Сааскытын хахсаатынан билэн, Сайыннытын самыырынан сабақалаан, Кыһыннытын кырыатынан кыйдаран...

(Каратаев, 1996: 120).
Осень по ненастью узнавая, Весну по заморозкам ощущая, Лето по дождю определяя, Зиму по инею распознавая...

(Каратаев, 1996: 121).

Как видно из формул, если в тувинском примере описывается продолжительность борьбы между богатырями, то в якутском - продолжительность богатырского похода в Нижний мир. При этом темпоральность описываемых действий раскрывается посредством одинаковой конструкции РСП, основанной на чередовании времен года. Поразительное сходство этих примеров объясняется тем, что в них используется одинаковая матричная конструкция, основанная на ядерных словосочетаниях: кыш хыраазындан - ‘зиму по инею’ / кыһынгытын кырыатынан - ‘зиму по инею’; чайның шалыңындап ‘лето по росе’ / сайыннытын самыырынан - ‘лето по дождю’. В первых ядерных словосочетаниях наблюдается полная эквивалентность. Однако, если в якутском олонхо применены все четыре сезона, то в тувинском только основные - зима и лето. На наш взгляд, это обстоятельство объясняется стадиальным отличием тувинского эпоса от якутского олонхо.

Формула, описывающая стрельбу из лука:

Ок туткан холунуң

Оду буругайнып,

Ча туткан холундан

Чалбырааш чайыгайнып келген...

(Ооржак, 1997: 342).

\section{Эрбэђиттэн}

Этин эттэ,

Тарбақыттан

Чақыльан чақылыйда, ...

(Нохсоров, 2009: 227).
И, когда от руки, державшей стрелу,

Вспыхнул огонь,

От руки, державшей лук,

Сверкнуло яркое пламя... (Ооржак, 1997: 343).

Из большого пальца

Гром прогремел,

Из указательного пальца

Молния сверкнула...

(Пер. наш. - Ю. Б.).

В этих примерах описывается момент стрельбы богатырей из лука - одного из основных предметов богатырского снаряжения. Несмотря на то, что в тувинском эпосе богатырь стреляет только тогда, когда на его руках вспыхивает огонь и сверкает пламя, а в якутском олонхо гром и молния происходят только после его стрельбы, эти формулы являются однотипными. Однотипность исходит из одинаковой структуры РСП и схожей семантической нагрузки, заключенных в ядерных лексемах, выраженных контекстными синонимами: хол - ‘рука' / эрбэх - ‘большой палец’ / тарбах - ‘палец’; от - ‘огонь' / чалбырааш - ‘пламя’; этин - ‘гроза' / чађыльан - ‘молния’.

Формула, описывающая тоску и печаль:

Дүн болурга, дүштен ыравас,

Хүндүс сагыштан-даа ыравас бооп кээрге...

Ночь настанет - из снов не уходят,

День [настанет] - из дум не уходят.

(Ооржак, 1997: 470).

(Ооржак, 1997: 471).

Түунүн түһүөн билэбин,

Күнүһүн бүттэнэн билэбин...

(Хаан Дьаргыстай: ..., 2016: 68).

Ночью снами предугадываю,

Днем предчувствием узнаю...

(Пер. наш. - Ю. Б.).

В тувинском примере описывается тоска богатыря по родителям, которых угнал в рабство враждебный хан, а в якутском - горесть прекрасной девушки, которую выдали замуж против её воли и она печалится о предстоящей жизни с нелюбимым, предчувствует сложные отношения. Однако, несмотря на различие описываемых ситуаций в семантическом и структурном плане, эти формулы весьма близки. Близость их исходит из эквивалентных оппозиционных по отношению друг к другу лексем $\partial ү н$ 
/ түүн - 'ночь'; хүндүс / күнүс - 'день' и синонимичных дүш / түһээ - ‘видеть во сне' ядерных лексем матричной конструкции. Кроме того, во вторых членах РСП наблюдаются вариативные ядерные лексемы, выраженные контекстными синонимами: сагыш - 'мысль, дума' / бүт (лит. бит) - 'примета, предзнаменование; предчувствие'. А периферийные элементы в обеих формулах подобраны по принципу дословного повтора.

Формула, описывающая появление врага:

Дээрден бир кээп боор,

Чер алдындан кээп боор. (Ооржак, 1997: 510).

Үөһээттэн үргүөр буолан

Үргүйбэттэрэ буолуоба, Алларааттан атара буолан Күөрэйбэттэрэ буолуоқа...

(Каратаев, 1996: 188)
Может вдруг с неба явиться,

Может из-под земли явиться.

(Ооржак, 1997: 511).

Став сквозняком,

Сверху холодом веять не будут же,

Став острогой,

Снизу вынырнуть не посмеют же...

(Каратаев, 1996: 189).

Как в тувинском эпосе, так и в якутском олонхо, появление врага описывается сходными локативными эпическими формулами, выраженными двучленными РСП. Сходность обнаруживается в ядерных оппозиционных лексемах, выраженных контекстными синонимами: дээрден - 'с неба' / үөһэттэн - ‘сверху'; чер алдындан - ‘из-под земли' / алларааттан - 'снизу', которые указывают на направление, откуда должен появиться враг. Также в этих формулах особую функциональную роль играет дословное повторение, которое организует периферийные элементы в матричную структуру. При этом в якутской формуле организующее начало также несет и начальная аллитерация.

\section{Заключение}

Таким образом, проанализировав эпические формулы из текста тувинского эпоса «Боктуг Кириш, Бора Шээлей» сказителя М. Н. Ооржака и их аналогов из текстов якутских олонхо, можно установить, что рассмотренные примеры являются типическими местами. Универсальность этих формул заключается в их способности переходить от текста к тексту без существенных изменений в структуре и семантической нагрузке.

Структура эпических формул в тувинском эпосе организована посредством двучленного ритмикосинтаксического параллелизма, которому в якутском олонхо соответствуют формулы, состоящие как из двучленных, так и многочленных параллелизмов. На наш взгляд, это обстоятельство свидетельствует о стадиальном отличии сравниваемых эпических систем.

Семантическая нагрузка эпических формул исходит из ядерных лексем и периферийных элементов, которые подобраны по принципам дословного повтора и начальной аллитерации. Отдельно следует отметить параллели в матричных конструкциях, отражающих ментальное состояние персонажей, темпоральность и локативность, которые благодаря наличию как эквивалентных ядерных лексем, так и дословных повторов являются особо устойчивыми.

В связи с вышеизложенным мы склонны считать, что рассмотренные параллели эпических формул являются результатом генетического родства тувинского эпоса и якутского олонхо, которые сохранились благодаря основному принципу организации эпического стиха - принципу ритмикосинтаксического параллелизма.

\section{СПИСОК ЛИТЕРАТУРЫ}

Артеменко, Е. Б. (1985) Фольклорная формульность и вариативность в аспекте текстообразования // Язык русского фольклора: Межвузовский сборник / отв. ред. 3. К. Тарланов. Петрозаводск : Петрозаводский гос. ун-т. 162 c. C. $4-12$.

Бурнашев, Н. П. (1993) Якутский героический эпос. Кыыс Дэбилийэ // Памятники фольклора народов Сибири и Дальнего Востока / сказитель Н. П. Бурнашев; запись С. К. Дьяконова; подготовка текста Н. П. Дмитриева и др. Новосибирск : Наука. Т. 4.330 с. С. 9-25. 
Габышева, Л. Л. (2009) Фольклорный текст. Семиотические механизмы устной памяти. Новосибирск : Наука. 143 c.

Гоголева,М.Т.(2015) К проблеме генетических связей олонхо и тувинских героических сказаний //Гуманитарные исследования в Восточной Сибири и на Дальнем Востоке. № 1. С. 90-96.

Гринцер, П. А. (1975) Эпические формулы в «Махабхарате» и «Рамаяне» // Типологические исследования по фольклору : сборник статей памяти В. Я. Проппа / отв. ред., Д. А. Ольдерогге. М. : Наука. 320 с. С. 156-181.

Дмитриев, П. Н. (1978) Эпические формулы в олонхо // Эпическое творчество народов Сибири и Дальнего Востока: материалы Всесоюзной конференции фольклористов / ред. Н. В. Емельянов, В. Т. Петров. Якутск : Якутский филиал изд-ва СО АН СССР. 230 с. С. 118-120.

Жирмунский, В. М. (1964) Ритмико-синтаксический параллелизм как основа древнетюркского народного эпического стиха // Вопросы языкознания. № 4. С. 3-24.

Жирмунский, В. М. (1968) О некоторых проблемах теории тюркского народного стиха // Вопросы языкознания. № 1. С. 23-42.

Жирмунский, В. М., Кононов, А. Н. (2007) Книга моего деда Коркута. Огузкий героический эпос. СПб. : Наука. Ленинградское отделение. 299 с.

Каратаев, В. О. (1996) Модун Эр Соқотох [Могучий Эр Соготох] / Памятники фольклора народов Сибири и Дальнего Востока. 10 т. Новосибирск : Наука. 440 с.

Кидайш-Покровская, Н. В., Мирбадалева, А. И. (1971) Традиционные элементы стиля в эпическом тескте // Текстологическое изучение эпоса / отв. ред. В. М. Гацак, А. А. Петросян. М. : Наука. 232 с. С. 64-96.

Кузьмина, Е. Н. (2005) Указатель типических мест героического эпоса народов Сибири. Новосибирск : СО РАН. 1383 c.

Лорд, А. Б. (1994) Сказитель. М. : Издательская фирма «Восточная литература». 368 с.

Нохсоров, У. Г. (2009) Дыырай Бэргэн. Якутский героический эпос. Якутск : Бичик. 334 с. (На як. яз.)

Окладников, А. П. (2013) Якутский эпос (олонхо), и его связь с югом. Якутск : Сайдам. 64 с.

Ооржак, М. Н. (1997) Боктуг-Кириш Бора-Шэлей // Тувинские героические сказания / Памятники фольклора народов Сибири и Дальнего Востока. Т. 12. Новосибирск : Наука. 584 с. С. 298-527.

Орус-оол, С. М. (1997) Тувинские героические сказания // Тувинские героические сказания / Памятники фольклора народов Сибири и Дальнего Востока. Новосибирск : Наука. Т. 12. 584 с. С. 10-38.

Орус-оол, С. М. (2013) Опыт классификации типических мест в разновременных записях эпоса «Тон-Аралчынхан» (по Указателю Е. Н. Кузьминой) // Новые российские гуманитарные исследования. Т. 8, № 8-8 (8). С. 51.

Оссовецкий, И. А. (1979) Некоторые наблюдения над языком стихотворного фольклора // Очерки по стилистике художественной речи / отв. ред. А. Н. Кожин. М. : Наука. 254 с. С. 199-252.

Покатилова, Н. В. (1996) К вопросу о формах параллелизма в эпическом жанре олонхо: из наблюдений над текстом // Язык - миф - культура народов Сибири : сборник научных статей / отв. ред. Л. Л. Габышева. Якутск : Изд-во ЯГУ. 192 с. С. 73-88.

Пухов, И. В. (2004) Якутский героический эпос - олонхо: публикация, перевод, теория, типология: избранные статьи. Якутск : Изд-во СО РАН, Якут. фил. 208 с.

Слепцов, П. А. (1990) Якутский литературный язык. Формирование и развитие общенациональных норм. Новосибирск : Наука. 227 с.

Хаан Дьаргыстай: олонхо (2016) / сост. В. В. Илларионов Дьокуускай : Алаас. 232 с. (На як. яз.)

Хертек, Л. К. (2015) К вопросу о лингвистическом анализе эпических текстов // Филологические науки. Вопросы теории и практики. № 12 (54): в 4-х ч. Ч. І. С. 188-190.

Ядрихинский, П. П. (2011) Девушка богатырь Джырыбына Джырылыатта. Якутский героический эпос. Якутск : Сайдам. 448 с.

Яковлев, Н. П. (2013) Даадар-Хара: олонхо. Дьокуускай : ХИФУ издательскай дьиэтэ. 296 с. (На як. яз.)

Яковлев, С. С. (1993) Буура Дохсун: олонхо. Дьокуускай : Бичик. 413 с. (На як. яз.)

Дата поступления: 12.07.2020 г.

\section{REFERENCES}

Artemenko, E. B. (1985) Fol'klornaia formul'nost' i variativnost' v aspekte tekstoobrazovaniia [Folklore formulas and variations through the lens of text formation]. In: Iazyk russkogo fol'klora [Language of Russian folklore]: interuniversity collection / ed. by Z. K. Tarlanov. Petrozavodsk, Petrozavodskii gos. un-t. 162 p. Pp. 4-12. (In Russ.).

Burnashev, N. P. (1993) Iakutskii geroicheskii epos «Kyys Debiliie» [Yakut heroic epic "Kyys Debiliye”]. In: Pamiatniki fol'klora narodov Sibiri i Dal'nego Vostoka [Folklore texts of the peoples of Siberia and the Far East] / told by N. P. Burnashev; recorded by S. K. Diakonov; text prep. by N. P. Dmitriev et al. Novosibirsk, Nauka. T. 4. 330 p. Pp. 9-25. (In Russ.). 
Gabysheva, L. L. (2009) Fol'klornyi tekst. Semioticheskie mekhanizmy ustnoi pamiati [Folklore text: Semiotic mechanisms of oral memory]. Novosibirsk, Nauka. 143 p. (In Russ.).

Gogoleva, M. T. (2015) K probleme geneticheskikh sviazei olonkho i tuvinskikh geroicheskikh skazanii [On the problem of genetic connections between Olonkho and Tuvan heroic tales]. Gumanitarnye issledovaniia $v$ Vostochnoi Sibiri $i$ na Dal'nem Vostoke, no. 1, pp. 90-96. (In Russ.).

Grintser, P. A. (1975) Epicheskie formuly v «Makhabkharate» $\mathrm{i}$ «Ramaiane» [Epic formulas in the "Mahabharata" and "Ramayana”]. In: Tipologicheskie issledovaniia po fol'kloru [Typological studies in folklore]: a collection of articles in memory of V. Ya. Propp / ed. by D. A. Ol'derogge. Moscow, Nauka. 320 p. Pp. 156-181. (In Russ.).

Dmitriev, P. N. (1978) Epicheskie formuly v olonkho [Epic formulas in the Olonkho]. In: Epicheskoe tvorchestvo narodov Sibiri i Dal'nego Vostoka [Epic of the peoples of Siberia and the Far East]: Proceedings of the all-Union conference of folklorists / ed. by N. V. Emel'ianov and V. T. Petrov. Yakutsk, Yakutskii filial izd-va SO AN SSSR. 230 p. Pp. 118-120. (In Russ.).

Zhirmunskii, V. M. (1964) Ritmiko-sintaksicheskii parallelizm kak osnova drevnetiurkskogo narodnogo epicheskogo stikha [Rhythmic and syntactic parallelism as the basis of ancient Turkic folk epic verse]. Voprosy iazykoznaniia, no. 4, pp. 3-24. (In Russ.).

Zhirmunskii, V. M. (1968) O nekotorykh problemakh teorii tiurkskogo narodnogo stikha [On some issues of the theory of Turkic folk verse]. Voprosy iazykoznaniia, no. 1, pp. 23-42. (In Russ.).

Zhirmunskii, V. M. and Kononov, A. N. (2007) Kniga moego deda Korkuta. Oguzkii geroicheskii epos [The book of my grandfather Korkut. Oghuz heroic epic]. St. Petersburg, Nauka. Leningradskoe otdelenie. 299 p. (In Russ.).

Karataev, V. O. (1996) Modun Er So̧otokh [Mighty Er Sagoth]. In: Pamiatniki fol'klora narodov Sibiri i Dal'nego Vostoka [Folklore texts of the peoples of Siberia and the Far East] / told V. O. Karataev; tr. by P. E. Efremov et al. Novosibirsk, Nauka. Vol. 10. 440 p. Pp. 10-58. (In Russ.).

Kidaish-Pokrovskaia, N. V. and Mirbadaleva, A. I. (1971) Traditsionnye elementy stilia v epicheskom teskte [Traditional elements of style in an epic text]. In: Tekstologicheskoe izuchenie eposa [Textual study of the epic] / ed. by V. M. Gatsak and A. A. Petrosian. Moscow, Nauka. 232 p. Pp. 64-96. (In Russ.).

Kuz'mina, E. N. (2005) Ukazatel' tipicheskikh mest geroicheskogo eposa narodov Sibiri [Index of typical places of the heroic epic of the peoples of Siberia]. Novosibirsk, SO RAN. 1383 p. (In Russ.).

Lord, A. B. (1994) Skazitel' [Taleswapper]. Moscow, Publishing company “Vostochnaia literature”. 368 p. (In Russ.).

Nokhsorov, U. G. (2009) Dyyrai Bergen. Iakutskii geroicheskii epos [Dyyrai Bergen: Yakut heroic epic]. Yakutsk, Bichik. 334 p. (In Yakut.)

Okladnikov, A. P. (2013) Yakutskii epos (olonkho), i ego sviaz' s iugom [Yakut epic (the Olonkho), and its connection with the South]. Yakutsk, Saidam. 64 p. (In Russ.).

Oorzhak, M. N. (1997) Boktug-Kirish Bora-Shelei. In: Tuvinskie geroicheskie skazaniia / Pamiatniki fol'klora narodov Sibiri i Dal'nego Vostoka [Tuvan heroic tales / folklore texts of the peoples of Siberia and the Far East]. Novosibirsk, Nauka. Vol. 12. 584 p. Pp. 298-527. (In Russ.).

Orus-ool S. M. (1997) Tuvinskie geroicheskie skazaniia [Tuvan heroic tales]. In: Tuvinskie geroicheskie skazaniia / Pamiatniki fol'klora narodov Sibiri i Dal'nego Vostoka [Tuvan heroic tales / folklore texts of the peoples of Siberia and the Far East]. Novosibirsk, Nauka. Vol. 12. 584 p. Pp. 10-38. (In Russ.).

Orus-ool, S. M. (2013) Opyt klassifikatsii tipicheskikh mest v raznovremennykh zapisiakh eposa “Ton-Aralchyn-khan” (po Ukazateliu E. N. Kuz'minoi) [An attempt at classification of typical places in different time records of the epic "TonAralchyn-Khan" (according to the Index by E. N. Kuzmina)]. Novye rossiiskie gumanitarnye issledovaniia, vol. 8, no. 8-8 (8), p. 51. (In Russ.).

Ossovetskii, I. A. (1979) Nekotorye nabliudeniia nad iazykom stikhotvornogo fol'klora [Some observations on the language of poetic folklore]. In: Ocherki po stilistike khudozhestvennoi rechi [Essays on the style of artistic speech] / ed. by A. N. Kozhin. Moscow, Nauka. 254 p. Pp. 199-252. (In Russ.).

Pokatilova, N. V. (1996) K voprosu o formakh parallelizma v epicheskom zhanre olonkho: iz nabliudenii nad tekstom [On the question of forms of parallelism in the Olonkho epic genre: from observations on the text]. In: Iazyk - mif - kul'tura narodov Sibiri [Language-myth-culture of the peoples of Siberia]: collection of scientific articles / ed. by L. L. Gabysheva. Yakutsk, YaGU Publ. 192 p. Pp. 73-88. (In Russ.).

Pukhov, I. V. (2004) Yakutskii geroicheskii epos - olonkho: publikatsiia, perevod, teoriia, tipologiia: izbrannye stat'i [Yakut heroic epic - Olonkho: publication, translation, theory, typology: selected articles]. Yakutsk, SO RAN Publ., Yakut brunch. 208 p. (In Russ.).

Sleptsov, P. A. (1990) Yakutskii literaturnyi iazyk. Formirovanie i razvitie obshchenatsional'nykh norm [Yakut literary language. Formation and development of national standards]. Novosibirsk, Nauka. 227 p. (In Russ.).

Khaan D'argystai: оlorkho (2016) / comp. by V. V. Illarionov D'okuuskai, Alaas. 232 p. (In Yakut.)

Khertek, L. K. (2015) K voprosu o lingvisticheskom analize epicheskikh tekstov [On the issue of linguistic analysis of epic texts]. Filologicheskie nauki. Voprosy teorii i praktiki, no. 12 (54): in 4 parts. Part I. Pp. 188-190. (In Russ.). 
Yadrikhinskii, P. P. (2011) Devushka bogatyr' Dzhyrybyna Dzhyrylyatta. Iakutskii geroicheskii epos [Djyrybyna Djyrylyatta, the Warrior woman. Yakut heroic epic]. Yakutsk, Saidam. 448 p. (In Russ.).

Yakovlev, N. P. (2013) Daadar-Khara: olonkho. D'okuuskai, KhIFU. 296 p. (In Yakut.)

Yakovlev, S. S. (1993) Buura Dokhsun: olonkho. D'okuuskai, Bichik. 413 p. (In Yakut.)

Submission date: 12.07.2020. 